\title{
Utilization of over-ripened fruit (waste fruit) for the eco-friendly production of ethanol
}

\author{
Rishabh Chitranshi ${ }^{1} \cdot$ Raj Kapoor $^{2}$
}

Received: 24 June 2020 / Revised: 4 August 2020 / Accepted: 7 August 2020 / Published online: 5 February 2021

(c) Society for Plant Research 2021

\begin{abstract}
This research was carried out to produce ethanol for use as a sanitizer in today's COVID-19 pandemic situation, via costeffective and eco-friendly techniques. The waste of seasonal fruit, i.e. apple, grape and Indian blueberry, was used in the study. Saccharomyces cerevisiae (baker's yeast) was used with $\mathrm{KMnO}_{4}(5 \%)$, sucrose $(47 \mathrm{~g})$ and urea $(1.5 \mathrm{~g})$ for the fermentation process. All the selected overripe fruits were analyzed for variations in parameters including specific gravity, $\mathrm{pH}$, temperature and concentration during complete fermentation for ethanol production. After complete fermentation, it was clear that the use of Indian blueberry at a temperature of $33{ }^{\circ} \mathrm{C}$, specific gravity of 0.875 and $\mathrm{pH}$ value of 5.2 yielded the highest ethanol concentration of $6.5 \%$. The concentration of ethanol obtained from grape samples was $5.23 \%$ at $30{ }^{\circ} \mathrm{C}$ with specific gravity of 0.839 and $\mathrm{pH} 4.3$. Lastly, the ethanol concentration obtained from apple waste was about $4.52 \%$ at $32{ }^{\circ} \mathrm{C}$ with specific gravity of 0.880 and $\mathrm{pH}$ of $4.7 \mathrm{pH}$. The FTIR curve of each sample shows an absorbance peak in a wave number range of $3000 \mathrm{~cm}^{-1}$ to $3500 \mathrm{~cm}^{-1}$, which indicates the absence of alcohol in the samples after fermentation.
\end{abstract}

Keywords Fruit waste $\cdot$ Bioethanol $\cdot$ Alcoholic fermentation

\section{Introduction}

A wide range of organic chemicals are produced commercially via fermentation using different microorganisms (Robak and Balcerek 2018). The industrial production of ethanol via traditional chemical methods involve the reaction between ethylene and steam at high pressure in the presence of extreme temperatures (Lin et al. 2017). This process has various adverse effects on the environment. Biofuels are emerging worldwide as an alternative because of their industrial and economic value. They pose no threat to the environment, thus helping to reduce greenhouse gases and provide energy security, which is leading to their growing use (Sharma 2015; Liang 2013). The production of biofuels using biomass

Rishabh Chitranshi

rishabh.chitranshi12@gmail.com

1 Department of Microbiology, School of Biomedical and Pharmaceutical Sciences, Babasaheb Bhimrao Ambedkar University, Lucknow 226025, India

2 Department of Testing and Certification, National Collateral Management Limited, 46 B/11, Co-operative Industrial Area, Dada Nagar, Kanpur 208022, India from microalgae or other waste represents an important effort to save nature and the environment which are being exploited by using harmful chemical substances around the globe (Behera et al. 1996; Fukuda et al. 2009; Singh et al. 2016; Sarmah et al. 2019; Shah et al. 2019). Ethanol has long been considered as a suitable alternative to fossil fuels. Moreover, bioethanol is not a petroleum product and can be easily synthesized via agricultural feedstock or fruit waste, which makes it a suitable industrial chemical (Jahid et al. 2018). A huge amount of fruit waste and residues are generated after industrial processing of various fruit crops. Such waste includes apple, grapes, Indian blueberry, citrus (oranges, lemons, limes, mandarins) and banana (Kosseva 2017). These fruit wastes have very good antimicrobial and antioxidant potential, with high levels of fermentable soluble sugars (glucose, sucrose and fructose) that can be converted or broken down into bioethanol after fermentation. Because they are a ubiquitous and renewable resource, fruit wastes have proven to be an useful source of waste biomass for ethanol production (Zabed et al. 2014). However, the chemical composition may vary between different ripening stages, particularly in terms of sugar and ethanol concentrations (Dudley 2004). Further, due to the hydrolysis of starch 
present in overripe fruits, the conversion of soluble sugars into alcohol takes place (Singh et al. 1984). Fermentation of ethanol converts sugar into cellular energy and produces ethanol and $\mathrm{CO}_{2}$ as end products. The alcoholic fermentation converts $1 \mathrm{~mol}$ of glucose into $2 \mathrm{~mol}$ of ethanol and $2 \mathrm{~mol}$ of carbon dioxide, producing $2 \mathrm{~mol}$ of ATP in the process $\left(\mathrm{C}_{6} \mathrm{H}_{12} \mathrm{O}_{6} 2 \mathrm{C}_{2} \mathrm{H}_{5} \mathrm{OH}+2 \mathrm{CO}_{2}\right)$ (Baskar et al. 2012). Ethanol $\left(\mathrm{CH}_{3} \mathrm{CH}_{2} \mathrm{OH}\right)$, also known as ethyl alcohol or grain alcohol, is a volatile, flammable, colorless and synthetic oxygen-containing organic chemical compound which is commonly used in antibacterial hand sanitizer gels, medical wipes and antiseptic liquid gels (Gold et al. 2018). In addition, its unique properties allow it to act as a solvent, disinfectant, antifreeze and chemical intermediate for biofuels and other organic chemicals (Kerton and Marriott 2013). Today, as the whole world is battling OVID-19 pandemic, the use of sanitizer will be a part of good hygiene practice to protect ourselves from this dreaded virus. However, in the current scenario, the country needs abundant hand sanitizer gels, medical wipes and antiseptic liquids. Therefore, the production of bioethanol in the country by small-scale industries through fruit wastes will be an essential, eco-friendly and cost-effective alternative (Balat and Balat 2009; Anwar et al. 2014).

In this study, three different fruit wastes, namely apple, grape and Indian blueberry were used for the comparative study of ethanol production and efficiency via a fermentation method. To calculate the efficiency of ethanol production, parameters including specific gravity, temperature, $\mathrm{pH}$ and concentration were measured. Apple (Malus pumila) was used as a source for the production of ethanol because it has high sugar (fructose, glucose and sucrose) content (Zabed et al. 2017). Overripe grape (Vitis vinifera) waste was used as a substrate in this experiment because grapes contain naturally high levels of sugar content of around $26 \mathrm{~g}$ in $100 \mathrm{~g}$ of grape juice, which is much higher than the natural sugar levels found in maize, sugarcane and beetroot (Mansouri et al. 2016). Blueberries (Vaccinium spp.) are a good source of super antioxidant function. They have approximately $15 \mathrm{~g}$ of sugar, $21 \mathrm{~g}$ of carbohydrates and $3.6 \mathrm{~g}$ of fiber found in $100 \mathrm{~g}$ of blueberries, and thus were used as a substrate for ethanol production. All these fruits are cost-effective seasonal fruits which are easily available as feedstock for ethanol production in the local market. Thus, the main aim of this study is to analyze the efficiency and percentage of ethanol obtained from different fruit waste for best-quality sanitizer production.

\section{Material and methods}

\section{Sample collection and preparation}

An appropriate quantity of overripe fruits (waste fruit) including apple, grape and Indian blueberry were randomly collected from the local fruit market located in the Alambagh area of Lucknow district in India. All the waste fruit was packed in sterilized poly bags and stored at room temperature in the laboratory for $24 \mathrm{~h}$. Approximately $200 \mathrm{~g}$ of the collected waste fruit was subjected to surface sterilization with $5 \%$ potassium permanganate $\left(\mathrm{KMnO}_{4}\right)$ solution followed by thorough rinsing twice with distilled water and air drying. All the samples were crushed individually in a mixer and collected in beakers for further study.

\section{Inoculum preparation for fermentation}

To prepare the inoculum, $20 \mathrm{~g}$ of dried yeast containing Saccharomyces cerevisiae (Lalvin ICV K1-V1116) was slowly blended with distilled water at $35-40{ }^{\circ} \mathrm{C}$ and left to activate for about $15 \mathrm{~min}$. The activated yeast was then mixed with $1.5 \mathrm{~g}$ urea and $47 \mathrm{~g}$ sucrose. This combination was used as an activated inoculum during the fermentation process for a fruit crush. The fruit crush and inoculum were transferred into a $2 \mathrm{~L}$ conical flask, and distilled water was added to a final volume of $1000 \mathrm{ml}$. The other two waste fruit crushed samples were prepared in the same manner, and the samples were then ready for the fermentation. The three flasks were then incubated at $35{ }^{\circ} \mathrm{C}$ at 150 rotations $\mathrm{min}^{-1}$ for 1 week; the incubation may have varied among samples. An un-inoculated control was maintained along with the test and incubated in a similar culture condition for comparison (Walker 2010; Lin and Tanaka 2006).

\section{Distillation of end product}

After completion of the fermentation process, the supernatants were separated from all samples, and specific gravity was checked by hydrometer as described in the first revision of the Indian Standards for wines (IS7585:1995; reaffirmed in 2000) and FSSAI manual (2015) to determine the percentage concentration of alcohol. The distillation was performed in a distillation assembly for about $4-6 \mathrm{~h}$. The distillation was optimized accordingly to obtain the maximum percentage of bioethanol in the final product. After filtration, the physicochemical analysis of parameters including $\mathrm{pH}$, temperature, concentration and the amount of ethanol obtained was made on the collected 
end products. All three solutions were also subjected to an iodine test to confirm the presence of ethanol (Dhanaseeli and Balasubramanian 2014).

\section{Fourier transform infrared spectroscopy (FTIR)}

The degradation levels of all the processed waste were also analyzed via Fourier transform infrared spectroscopy (FTIR) $(\alpha$ E-Fourier Transform Infrared Spectrophotometer, Bruker, USA) over a spectrum range of $500 \mathrm{~cm}^{-1}$ to $4000 \mathrm{~cm}^{-1}$ with fermented fruit waste samples. Pellets of the dried samples were prepared using $\mathrm{KBr}$ and scanned under the spectrum with a scanning frequency of 24 scans and resolution of $4 \mathrm{~cm}^{-1}$ (Godheja et al. 2017) (Fig. 1).

\section{Results and discussion}

It was clearly observed that in the process of ethanol production from fruit wastes, Indian blueberries at $33{ }^{\circ} \mathrm{C}$ produced the highest amount of ethanol (Fig. 2c), whereas grapes (Fig. 2b) ranked second at $30{ }^{\circ} \mathrm{C}$, and apple (Fig. 2a) produced the least amount of ethanol at $32{ }^{\circ} \mathrm{C}$. Moreover, the optimum temperature from beginning to end for fermentation ranged between $30^{\circ} \mathrm{C}$ and $33{ }^{\circ} \mathrm{C}$, which may vary according to the environmental conditions (Table 1). Studies have clearly shown that temperature plays a key role (Fig. 1b) in the process of fermentation, because there is a high level of enzymatic activity which is essential for the maximum growth of organisms, and these enzymes are activated at a particular temperature (Tesfaw and Assefa 2014). Variation in temperature may cause denaturation or unfolding of enzymes, making them slow or nearly inactive, and if one essential enzyme stops working, the organism fails to grow. The $\mathrm{pH}$ value also has a significant influence on the process of alcoholic fermentation (Fig. 1c). In this study, the $\mathrm{pH}$ of bioethanol produced from each of the fruit wastes ranged from 4.7 to 5.2. Indian blueberries with a $\mathrm{pH}$ value of 5.2 produced the best quality of ethanol among the three fruit wastes; grapes had a $\mathrm{pH}$ value of 4.3 , and apple had $\mathrm{pH}$ of 4.7. According to Wong and Sanggari (2014), the optimum $\mathrm{pH}$ for yeast to produce ethanol is 4.5 . The relation between temperature and $\mathrm{pH}$ is understood by another research study reporting that during an alcoholic fermentation process, the maximum amount of ethanol can be produced at temperatures between $30{ }^{\circ} \mathrm{C}$ and $35^{\circ} \mathrm{C}$ and pH of 5 to 6 (Ogbonda and David 2013). Apart from the temperature and $\mathrm{pH}$ value, specific gravity is generally used to measure the sugar content (Fig. 1a). However, when the alcoholic fermentation is at its peak, the specific gravity is significantly decreased and remains constant at a value of 0.860 for $48 \mathrm{hrs}$. The specific gravity of Indian blueberries was reduced to 0.875 and remained constant, whereas the specific gravity of grapes was reduced to 0.839 , and lastly, the specific gravity of apple
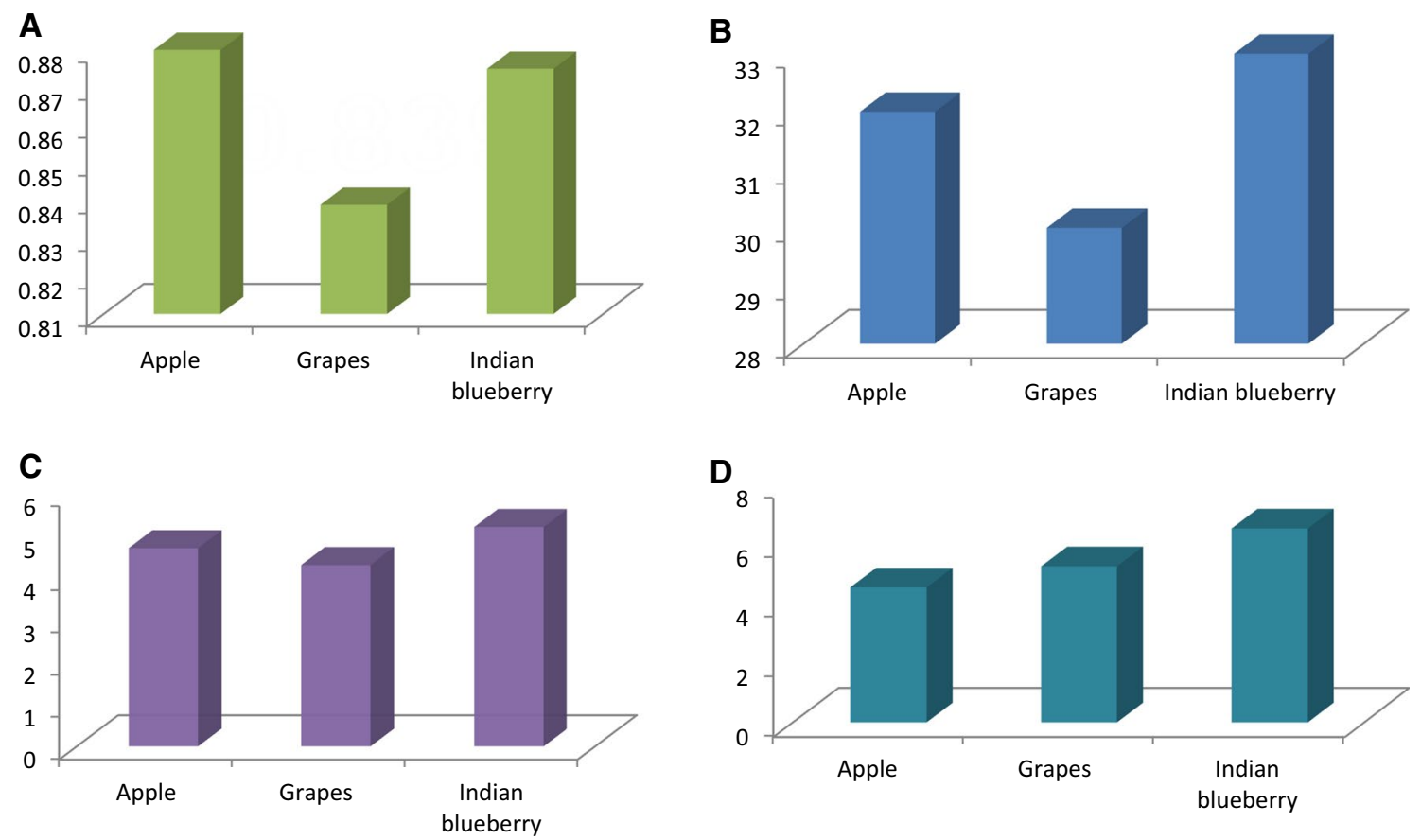

Fig. 1 Graph showing a specific gravity, $\mathbf{b}$ temperature, $\mathbf{c} \mathrm{pH}$ and $\mathbf{d}$ concentration for each fruit waste during fermentation 
Fig. 2 Graph showing: a apple, b grapes and $\mathbf{c}$ Indian blueberry for their optimum specific gravity, temperature, $\mathrm{pH}$ and concentration at which the bioethanol was produced after fermentation
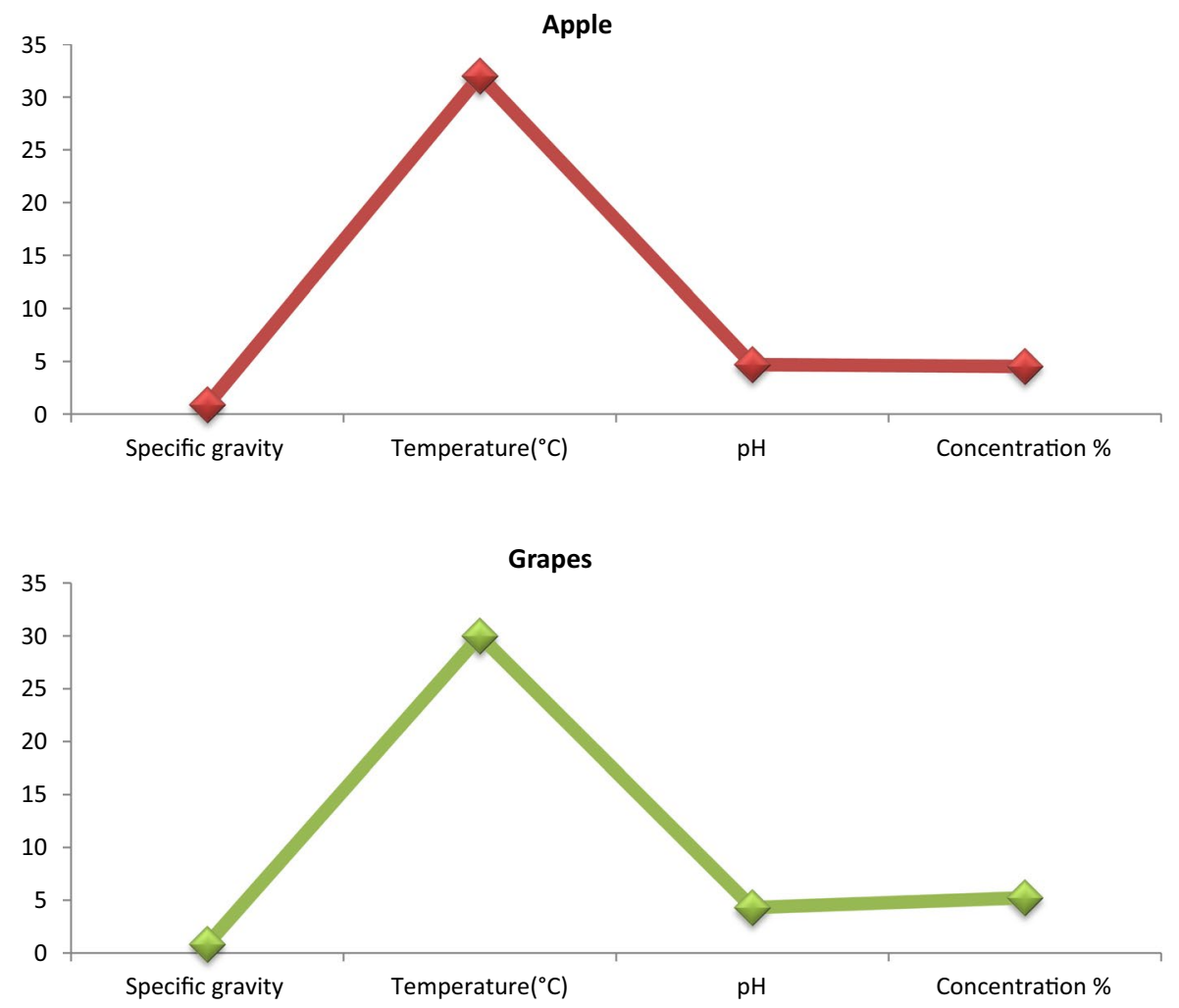

Indian blueberry

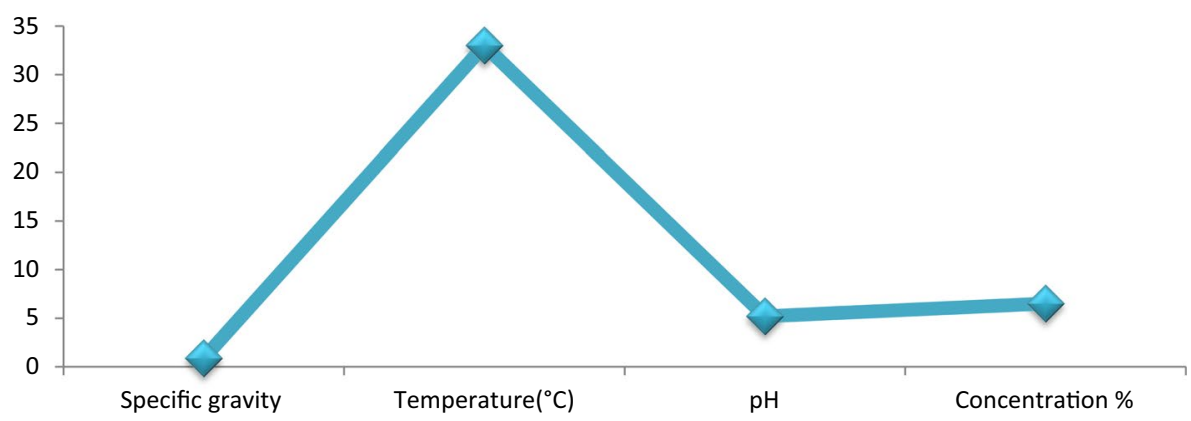

Table 1 Different parameters analyzed for bioethanol production via fruit wastes

\begin{tabular}{llllll}
\hline S. no. & Fruit & $\begin{array}{l}\text { Specific grav- } \\
\text { ity }\end{array}$ & $\begin{array}{l}\text { Tempera- } \\
\text { ture }\left({ }^{\circ} \mathrm{C}\right)\end{array}$ & $\mathrm{pH}$ & $\begin{array}{l}\text { Concen- } \\
\text { tration \% }\end{array}$ \\
\hline 1 & Apple & 0.880 & 32 & 4.7 & 4.52 \\
2 & Grapes & 0.839 & 30 & 4.3 & 5.23 \\
3 & $\begin{array}{c}\text { Indian blue- } \\
\text { berry }\end{array}$ & 0.875 & 33 & 5.2 & 6.5 \\
& & & & \\
\hline
\end{tabular}

was reduced to 0.880 at the peak of fermentation and remained constant. A continuous drop in the specific gravity indicates the conversion of sugar into ethanol in the alcoholic fermentation process via yeast, and the entire process of fermentation ends when the drop in the specific gravity is stabilized or remains constant after incubation (Bokulich and Bamforth 2013). Similarly, some research reports have concluded that the value of specific gravity has significant importance throughout the process of alcoholic fermentation (Gnansounou and Dauriat 2011). In the present study, the best concentration of ethanol was obtained in Indian blueberry, followed by apple and grapes (Fig. 1d). In the FTIR curve of each sample, an absorbance peak was found in a wave number range of $3000 \mathrm{~cm}^{-1}$ to $3500 \mathrm{~cm}^{-1}$ (slightly different in apple, grape and Indian blueberry samples) after fermentation, indicating that the polysaccharides were degraded during fermentation (Figs. 3, 4, 5). Sarkar et al. (2019) and Godheja et al. (2017) observed absorbance peaks between approximately $1000 \mathrm{~cm}^{-1}$ and $1320 \mathrm{~cm}^{-1}$ during the fermentation. Notably, high-efficacy ethanol can be produced by this process for medical, surgical or 


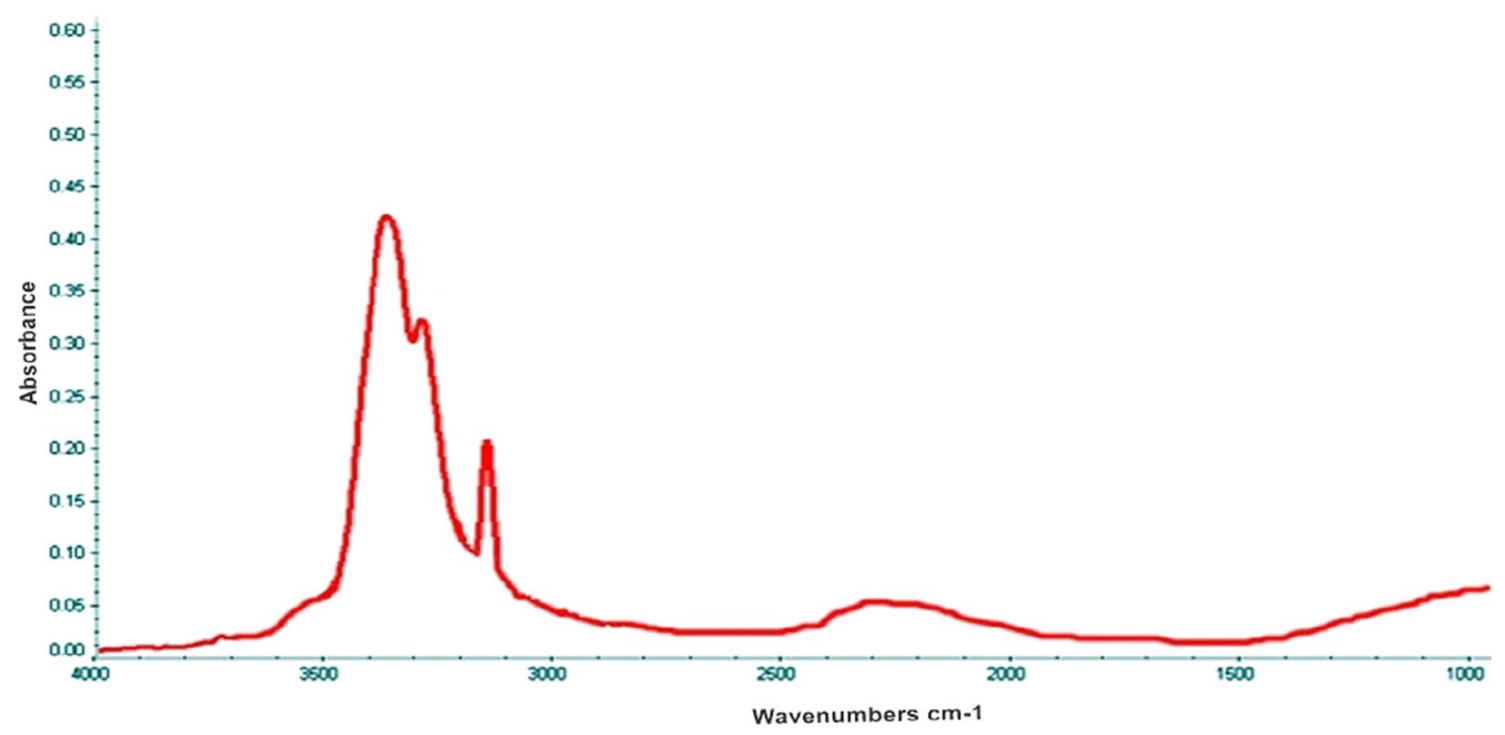

Fig. 3 FTIR analysis of grapes

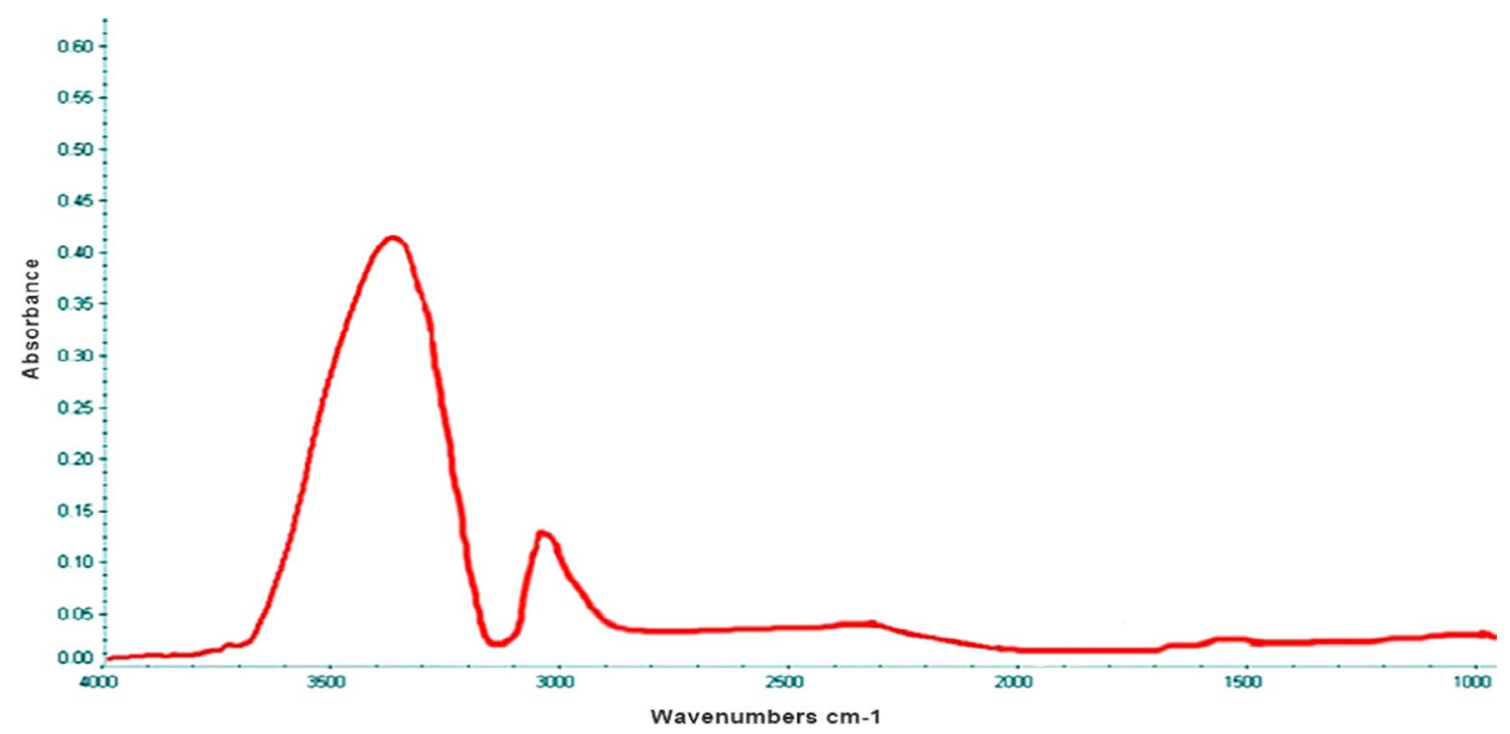

Fig. 4 FTIR analysis of apple

sanitization use without the high cost of industrial ethanol production. In this study, the high ethanol production may be subjected to the laboratory conditions during yeast fermentation, enzyme activity, etc. It is necessary to mention here that all the residues of fruit pulp waste generated after bioethanol production by this method were used to make biological compost, and the manure was used to increase the fertility of soil during organic farming.

\section{Conclusion}

Various types of fruit wastes can be used for the production of bioethanol. During this study, it was observed that Indian blueberry waste produced the highest amount of bioethanol with higher efficiency in comparison to other selected fruit wastes for production of sanitizers at optimum laboratory conditions. Also, the production of 


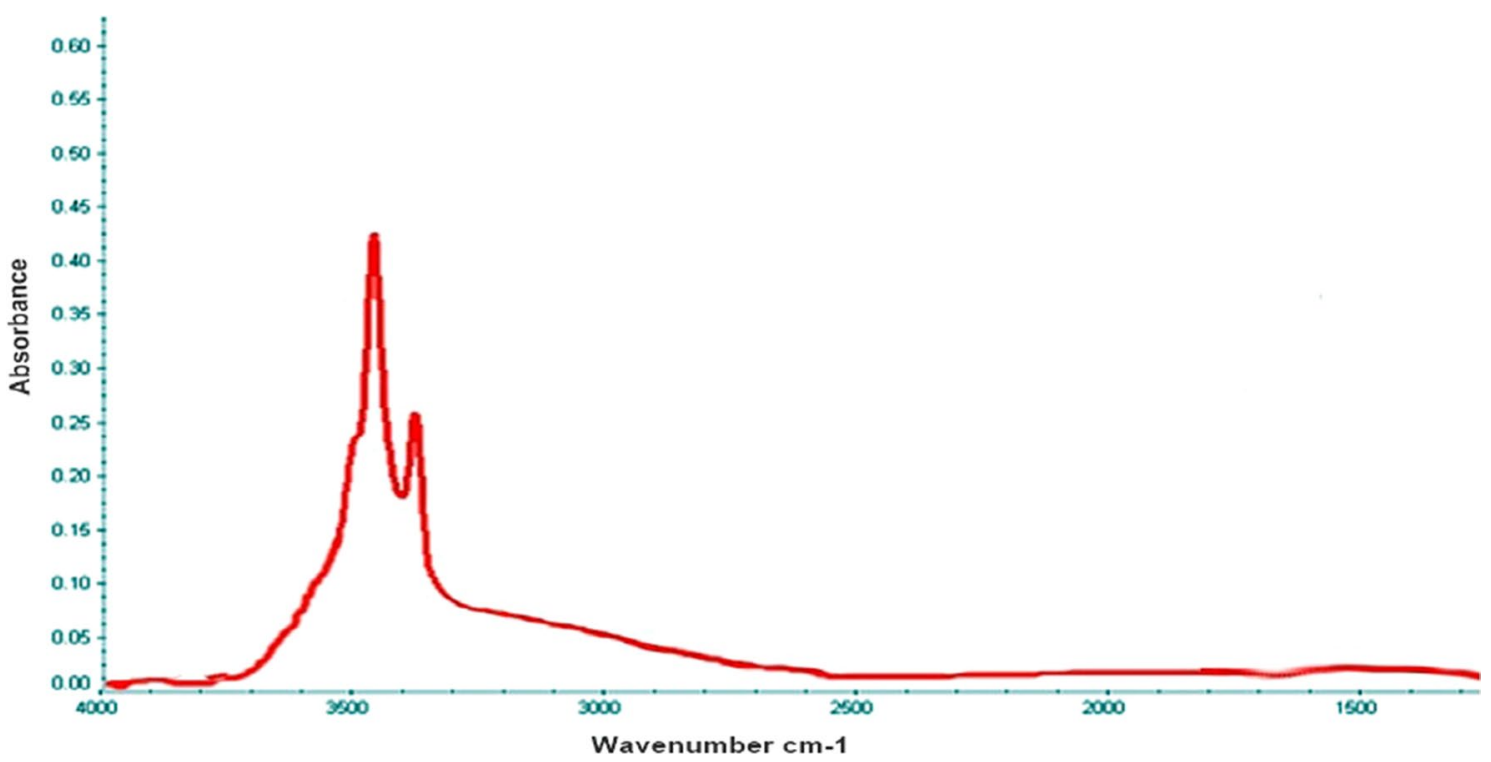

Fig. 5 FTIR analysis of Indian blueberries

bioethanol from this method is very cost-effective, which would prove very useful for small-scale industries.

Acknowledgements The authors are thankful to the Regional Food Research \& Analysis Centre, Udyan Bhawan Lucknow, UP, for providing research facility in their campus. The authors also express their gratitude to Dr. Mukesh from USIC BBA University Lucknow for helping in FTIR analysis.

\section{References}

Anwar Z, Gulfraz M, Irshad M (2014) Agro-industrial lignocellulosic biomass a key to unlock the future bio-energy: a brief review. J Radiat Res Appl Sci 7(2):163-173

Balat M, Balat H (2009) Recent trends in global production and utilization of bio-ethanol fuel. Appl Energy 86(11):2273-2282

Baskar C, Baskar S, Dhillon RS (eds) (2012) Biomass conversion: The interface of biotechnology, chemistry and materials science. Springer Sci \& Business Media, Berlin

Behera BK, Arora M, Sharma DK (1996) Scanning electron microscopic (SEM) studies on structural architecture of lignocellulosic materials of Calotropis procera during its processing for saccharification. Biores Technol 58(3):241-245

Bokulich NA, Bamforth CW (2013) The microbiology of malting and brewing. Microbiol Mol Biol Rev 77(2):157-172

Dhanaseeli PB, Balasubramanian V (2014) Studies of ethanol production from different fruit wastes using Saccharomyces cerevisiae. Biosci Biotechnol Res Asia 11:19-23 (Special edition)

Dudley R (2004) Ethanol, fruit ripening, and the historical origins of human alcoholism in primate frugivory. Integr Comp Biol 44(4):315-323

FSSI (2015) Manual of methods of analysis of foods. Alcoholic beverages, Ministry of health and family welfare, GOI, New Delhi

Fukuda H, Kondo A, Tamalampudi S (2009) Bioenergy: Sustainable fuels from biomass by yeast and fungal whole-cell biocatalysts. Biochem Eng J 44(1):2-12
Gnansounou E, Dauriat A (2011) Techno-economic analysis of lignocellulosic ethanol: A review. Bioresour Technol 101:4980-4991

Godheja J, Shekhar SK, Satyanarayan GNV, Singh SP, Modi DR (2017) Antibiotic and heavy metal tolerance of some indigenous bacteria isolated from petroleum contaminated soil sediments with a study of their aromatic hydrocarbon degradation potential. Int J Curr Microbiol Appl Sci 6:194-211

Gold NA, Mirza TM, Avva U (2018) Alcohol Sanitizer. In: StatPearls [Internet]. Available from: https://www.ncbi.nlm.nih.gov/books/ NBK513254/

Indian standard specifications- IS 7585:1995 Specifications for table wine, methods of analysis. Bureau of Indian Standards (BIS), New Delhi, India

Jahid M, Gupta A, Sharma DK (2018) Production of bioethanol from fruit wastes (banana, papaya, pineapple and mango peels) under milder conditions. J Bioprocess Biotechn 8(3):1-11

Kerton FM, Marriott R (2013) Alternative solvents for green chemistry. 2nd edn, RSC publishing, Cambridge

Kosava MR (2017) Waste from fruit wine production. In: Science and Technology of Fruit Wine Production. Academic Press, pp 557-598. https://doi.org/10.1016/C2013-0-13641-0

Liang S, Xu M, Zhang T (2013) Life cycle assessment of biodiesel production in China. Biores Technol 129:72-77

Lin Y, Tanaka S (2006) Ethanol fermentation from biomass resources: current state and prospects. Appl Microbiol Biotechnol 69(6):627-642

Lin L, Zhou W, Gao R, Yao S, Zhang X, Xu et al (2017) Low-temperature hydrogen production from water and methanol using $\mathrm{Pt} / \alpha-$ MoC catalysts. Nature 544(7648):80-83

Mansouri A, Rihani R, Laoufi AN, Özkan M (2016) Production of bioethanol from a mixture of agricultural feedstocks: biofuels characterization. Fuel 185:612-621

Ogbonda KH, Kiin-Kabari DB (2013) Effect of temperature and $\mathrm{pH}$ on ethanol production by a Blastomyces species isolated from the intestine of oil palm weevil (Rhynchophorus palmarum, coleoptera). Afr J Biotech 12(6):588-591

Robak K, Balcerek M (2018) Review of second generation bioethanol production from residual biomass. Food Technol Biotechnol 56(2):174-187 
Sarkar D, Prajapati S, Poddar K, Sarkar A (2019) Production of ethanol by Enterobacter sp. EtK3 during fruit waste biotransformation. Int Biodeter Biodegrad 145:104795. https://doi.org/10.1016/j.ibiod .2019 .104795

Sarmah P, Das S, Sharma H, Rout J (2019) Microalgal biomass generation by phycoremediation of sewage water: an integrated approach for production of antioxidant and value added products. Vegetos 32(4):556-563

Shah S, Sahoo D, Shukla RN, Mishra G (2019) De novo transcriptome sequencing of monodopsis subterranea ccala 830 and identification of genes involved in the biosynthesis of eicosapentanoic acid and triacylglycerol. Vegetos 32(4):600-608

Sharma DK (2015) Emerging biomass conversion technologies for obtaining value-added chemicals and fuels from biomass. Proceed Indian Nat Sci Acad 81(4):755-764

Singh A, Das K, Sharma DK (1984) Production of xylose, furfural, fermentable sugars and ethanol from agricultural residues. J Chem Technol Biotechnol Chem Technol 34(2):51-61

Singh JS, Kumar A, Rai AN, Singh DP (2016) Cyanobacteria: a precious bio-resource in agriculture, ecosystem, and environmental sustainability. Front Microbiol 7:529. https://doi.org/10.3389/ fmicb.2016.00529

Tesfaw A, Assefa F (2014) Current trends in bioethanol production by Saccharomyces cerevisiae: substrate, inhibitor reduction, growth variables, coculture, and immobilization. Int Scholar Res Notices. https://doi.org/10.1155/2014/532852

Walker GM (2010) Bioethanol: science and technology of fuel alcohol. Bookboon, London, p 116

Wong YC, Sanggari V (2014) Bioethanol production from sugarcane bagasse using fermentation process. Orient J Chem 30(2):507-513

Zabed H, Faruq G, Sahu JN, Azirun MS, Hashim R, Boyce NA (2014) Bioethanol production from fermentable sugar juice. Sci World J 2014:957102. https://doi.org/10.1155/2014/957102

Zabed H, Sahu JN, Suely A, Boyce AN, Faruq G (2017) Bioethanol production from renewable sources: current perspectives and technological progress. Renew Sustain Energy Rev 71:475-501

Publisher's Note Springer Nature remains neutral with regard to jurisdictional claims in published maps and institutional affiliations. 